\title{
Detection of Sentinel Lymph Nodes with Near-Infrared Imaging in Malignancies
}

\author{
Huan-Cheng Zeng, ${ }^{1,2}$ Jia-Lin Hu, ${ }^{3}$ Jing-Wen Bai, ${ }^{4}$ Guo-Jun Zhang ${ }^{2,4}$ \\ ${ }^{1}$ The Breast Center, Cancer Hospital of Shantou University Medical College, Shantou, Guangdong, China \\ ${ }^{2}$ ChangJiang Scholar's Laboratory, Shantou University Medical College, Shantou, Guangdong, China \\ ${ }^{3}$ Chancheng Center Hospital of Foshan, Foshan, Guangdong, China \\ ${ }^{4}$ Xiang'an Hospital, Xiamen University, No. 2000, Xiang'an East Road, Xiamen, 361101, Fujian, China
}

\begin{abstract}
Optical molecular imaging, a highly sensitive and noninvasive technique which is simple to operate, inexpensive, and has the real-time capability, is increasingly being used in the diagnosis and treatment of carcinomas. The near-infrared fluorescence dye indocyanine green (ICG) is widely used in optical imaging for the dynamic detection of sentinel lymph nodes (SLNs) in real time improving the detection rate and accuracy. ICG has the advantages of low scattering in tissue absorbance, low auto-fluorescence, and high signal-to-background ratio. The detection rate of axillary sentinel lymph nodes biopsy (SLNB) in breast cancers with ICG was more than $95 \%$, the false-negative rate was lower than $10 \%$, and the average detected number ranged from 1.75 to 3.8. The combined use of ICG with nuclein or blue dye resulted in a lower falsenegative rate. ICG is also being used for the sentinel node detection in other malignant cancers such as head and neck, gastrointestinal, and gynecological carcinomas. In this article, we provide an overview of numerous studies that used the near-infrared fluorescence imaging to detect the sentinel lymph nodes in breast carcinoma and other malignant cancers. It is expected that with improvements in the optical imaging systems together with the use of a combination of multiple dyes and verification in large clinical trials, optical molecular imaging will become an essential tool for SLN detection and image-guided precise resection.
\end{abstract}

Key words: Optical molecular imaging, Indocyanine green, Sentinel lymph nodes, Malignant cancers

\section{Introduction}

According to the WHO global cancer report in 2014, the global cancer incidence and mortality were about 14 million and 8 million, respectively [1]. Despite significant technological advances and a better understanding of the molecular defects, cancer remains a major cause of mortality and morbidity worldwide. In the surgical treatment areas, precise positioning of the tumor and the area of the incision are

Huan-Cheng Zeng and Jia-Lin Hu contributed equally to this work.

Correspondence to: Guo-Jun Zhang; e-mail: gjzhang@xah.xmu.edu.cn critical factors. In this respect, the biopsy of sentinel lymph nodes, which are the first lymph node(s) to receive the drainage from the primary tumor, is important in determining the spread of cancer as well as the staging of cancer [2].

The sentinel lymph node biopsy (SLNB) was first used by the surgical oncologist Morton, who applied the technique to the surgery of cutaneous melanomas [3]. In 1994, Giuliano et al. first performed SLNB in the breast cancer patients by using the blue dye, and the results showed an accuracy rate as high as $95 \%$ [4]. Around the same time, a radioisotope tracer was used in SLNB by Alex and Krag [5]. Furthermore, many large clinical trials proved the feasibility and accuracy of evaluating the status of axillary lymph nodes by using SLNB in breast 
cancers [6-8]. Besides breast cancers, SLNB is also used in the surgical treatment of other malignant cancers such as head and neck, gastrointestinal, and gynecological carcinomas. The traditional tracers for SLNB mainly include the blue dye, nuclein, and nanocarbon. However, use of these tracers in SLNB is time-consuming, and the experience of the surgeons also affects the detection rate and accuracy. Since the lack of realtime monitoring may lead to tissue injuries, some researchers applied the optical molecular imaging technique in SLNB [9].

With the advantages of simplicity in operation, noninvasiveness, real-time capability, high sensitivity, and cost effectiveness, optical molecular imaging is widely used in life sciences. In the clinical arena, optical molecular imaging is applied to diagnose very early-stage carcinomas. In 2010, Roger Tsien introduced the innovative fluorescence microscope imaging technology for intraoperative tumor visualization and precise excision [10].

Clinically, an appropriate tracer and a surgical navigation system are the important components of the optical molecular imaging technology. Because of their deep penetrating capacity and minimal absorbing ability in the tissues, the near-infrared light with wavelengths from 650 900 nm is known as tissue optical window. Compared with the visible light, the near-infrared light has the advantages of low scattering in the tissue absorbance, less auto-fluorescence, and high signal-to-background ratio. As one of the near-infrared fluorescent dyes, indocyanine green (ICG) [11] is low molecular weight, nontoxic, and quickly cleared by the hepatic route. With the absorption wavelength at $765 \mathrm{~nm}$, the emission wavelength at $840 \mathrm{~nm}$, and a high signal-to-background ratio, ICG is used in SLNB and is approved by the FDA (Food and Drug Administration) and EMA (European Medicines Agency) [12].

To meet the stringent requirements of real-time capability, safety, and convenience, each new imaging system must be thoroughly researched and developed prior to the clinical application. Based on their characteristics, the imaging systems fall into three categories:

1. Portable optical molecular imaging operation-guided systems. PDETM is an imaging equipment produced by the BinSong Photon Industry in Japan and looks like a flashlight. Another headset system with the advantage of keeping the surgeons' hands free was developed by the University of Washington [13].

2. Functional optical molecular imaging surgery-guided systems. Three cameras were used to collect the images in real time by the FLARETM Imaging System developed by the Harvard University [14]. Two of the cameras were used to collect the near-infrared fluorescence signal, while the other one collected the visual light signal for image infusion. Currently, FLARE ${ }^{\mathrm{TM}}$ and miniFLARE ${ }^{\mathrm{TM}}$ serve in the treatment of some malignant tumors, especially in SLNB. Another multi-spectral system developed by the Technical University Munich, Germany, also had been used in ovarian cancers [15]. The molecular image-guided surgery system
GXMA Navigator developed by Chinese Academy of Sciences has been used in the SLNB in breast cancers and gastric cancers [16].

3. The endoscopic optical molecular image-guided surgery system. In the dark environment in the coelom, surgeons can gain a high signal-to-background ratio through the endoscopic optical molecular imaging-guided surgery systems. Glatz [17] developed a laparoscopy system in which images were fused by the color and near-infrared fluorescence to position precisely the borders of colorectal tumors.

In this article, we have mainly discussed the application of the near-infrared fluorescence staining with ICG for the detection of sentinel lymph nodes in breast cancers and other malignant cancers such as head and neck cancers, gastrointestinal, and gynecological carcinomas (Figs. 1 and 2).

\section{ICG in SLN Detection in Breast Cancer}

\section{The Early Stage}

ICG was first used as a tracer for SLNB in 18 breast cancer patients in 2005 by Kitai et al. [19]. The lymph vessels were visible during the operation, and the SLNs were detected in 17 breast cancer patients with a detection rate of $94.4 \%(17 / 18)$. Subsequently, other research centers performed the same procedure in small studies. In 2008, Ogasawara et al. [20] utilized ICG as a tracer for SLNB in 37 breast cancer patients, and the detection rate was about $72.9 \%$ (27/37). Similarly, Murawa et al. [21] used ICG in 30 breast cancer patients and detected SLNs in $97 \%$ (29/30) of patients with the false-negative rate of $9.5 \%(2 / 21)$. The results of Hirche's group showed the detection rate of $97.7 \%$ (42/43) for SLNB of breast cancer patients using ICG, and the false-negative rate was $5.6 \%(1 / 18)$ [22].

\section{The Developing Stage}

With the advances in the fluorescence imaging-guided systems, both the images and technical operation have improved benefiting the surgeons in detecting the SLNs. A large number of patients were enrolled by many research centers for SLNB studies. In 2010, 142 breast cancer patients were enrolled by Hojo's group [23] showing a detection rate of $99.3 \%(140 / 142)$ in SLNs by using ICG, and the average number of nodes detected was about 3.8. Using a combined effort of three research centers [24], Sugie et al. reported a detection rate of $99 \%(408 / 411)$ in 411 patents and the average number of nodes detected was about 2.3. The metastatic lymph nodes were detected in 39 breast cancer patients, with $100 \%$ sensitivity.

As shown in Table 1, since 2010, ICG was applied to SLN detection in breast cancer patients in over 40 studies and the detection rates were almost over $95 \%$ [22, 25-30]. Some investigators compared the detection rates between ICG, blue 


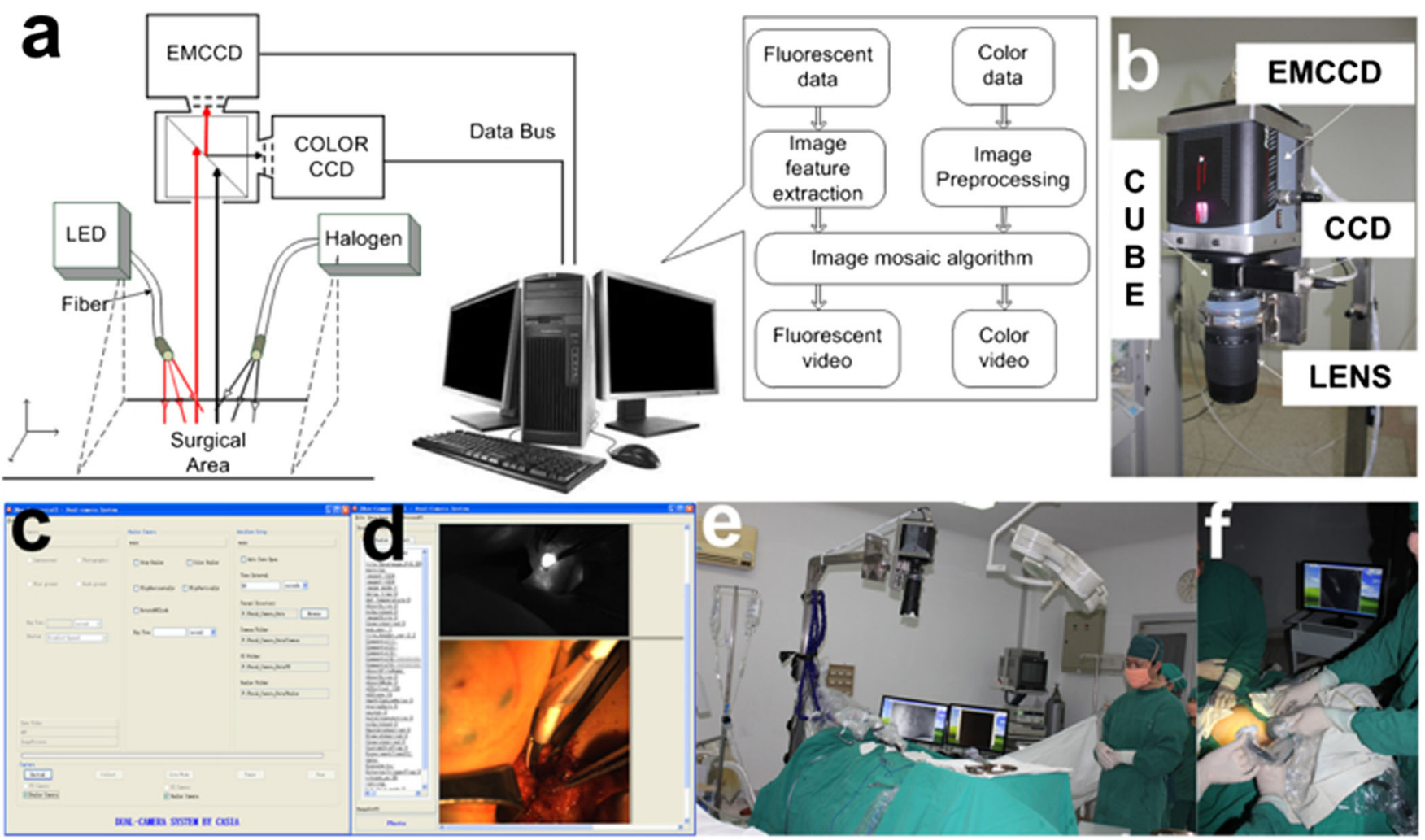

Fig. 1. Schematic diagram of the surgical navigation system and its application in surgery. a The principle figure of the surgical navigation system clarifying the operation course of the system. When the LED light illuminated the surgical area, the ICG dye emitted NIR light. The emission and reflection of the halogen light went through the lens to the prism. Then, the light was equally divided into two beams by the prism. One beam went through the filter to the color CCD and the other to the EMCCD. All of the data collected from the CCD were transferred to the computer, and the computer controlled the CCD. $\mathbf{b}$ The hardware of the surgical navigation system. c User interface of the software offering exposure time and auto capture interval time parameter settings. $\mathbf{d}$ Image acquisition interface as an example of the capture mode results. e Preoperative preparation in the operating room. $\mathbf{f}$ Intraoperative diagnosis with a surgical navigation system carried out during the surgery [16].

dye, and nuclein and noticed the better performance of ICG compared with the blue dye and nuclein. Sugie et al., together with three research centers, reported that the detection rate of SLN with blue dye was about $83-93 \%$, while it was up to $99.3 \%$ with ICG [24]. Samorani's group showed that the detection rates with ICG and nuclein in SLN of 301 patients were 98.7 and $95.3 \%$, respectively [29]. However, Sugie et al. reported comparable detection rates of 97.2 and $97.0 \%$ with ICG and nuclein, respectively, in 821 patients [30].

Some investigators analyzed the false-negative rate of ICG in SLNB and found it to be lower than $10 \%[22,24,26-28,30$ 33]. A meta-analysis of six studies, which used ICG as a tracer in SLNB of breast cancer patients, reported the sensitivity of about $92 \%$ (85\%-96\%) and the specificity of about $100 \%$ (97\%-100\%) [34]. When ICG was used with the blue dye or nuclein, the false-negative rate was decreased. With 86 enrolled patients, Guo and coworkers compared the false-negative rate between ICG and ICG with blue dye in 86 patients and showed $12 \%$ false-negative rate in the ICG group, while it was as low as $4 \%$ when the ICG was combined with blue dye [35]. Another study by Meng and colleagues also supported higher sensitivity and lower false-negative rate with ICG plus blue dye. The falsenegative rate was $11.1 \%$ with ICG alone and $3.4 \%$ with ICG plus blue dye [36]. The average number of SLNs detected with ICG ranged from 1.75 to 3.8 [21-25, 27, 29, 30, 35]. Murawa et al. reported the average number of detected SLNs to be 1.75, whereas [21] with the application of ICG, Hojo and colleagues detected an average number of 3.8 SLNs indicating the benefit of advance technology in improving SLNBs [23].

The largest study of SLNB in breast cancer patients so far was of 821 patients in which Sugie's group found the detection rate of $97.2 \%$ and the average number of SLNs detected was 2.3 in the ICG group, while the detection rate was $97 \%$ and average SLNs detection number was 1.7 in the nuclein group [30]. The detection rate increased to $99.8 \%$ by combining ICG with nuclein. Also, 180 cases had lymph node metastasis, and the false-negative rate decreased to $2.8 \%$ by combining ICG with nuclein which was lower than the $9.6 \%$ false-negative rate in a previous study that used nuclein and blue dye [6].

As for the safety profile of ICG, occurrence of allergic reactions was reported in $0.34 \%$, and severe side effects were rare occurring in $0.05 \%$ cases. Also, the incidence of side effects was related to the dosage of ICG and increased when the dosage exceeded $0.5 \mathrm{mg} / \mathrm{kg}$. However, in clinical practice, the dosage used is much less than $0.5 \mathrm{mg} / \mathrm{kg}$ [37]. Furthermore, the clinical follow-up data showed low recurrence rates of axillary 

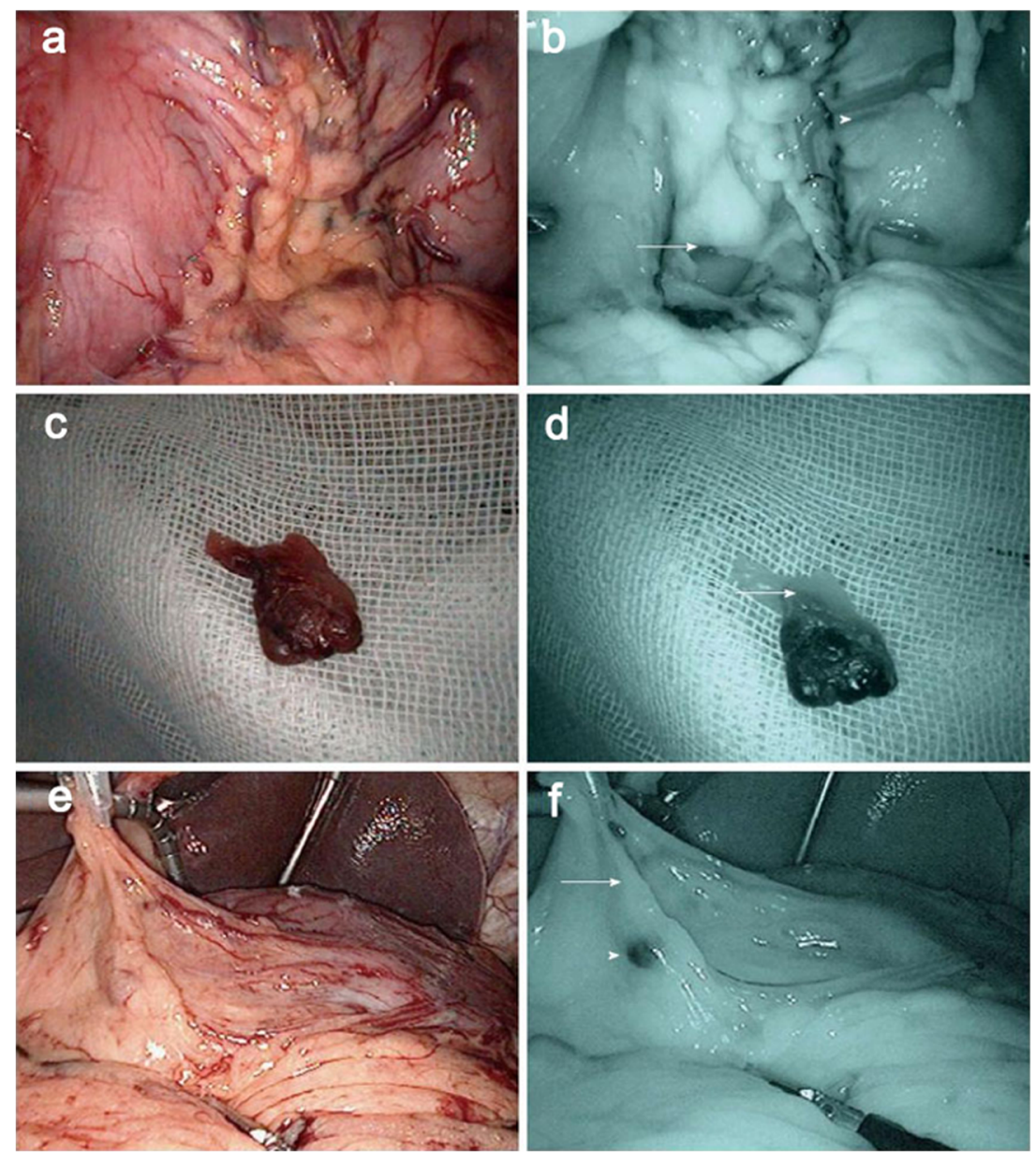

Fig. 2. Laparoscopic observation around the left gastric vessels. Lymph vessels and LN can be easily detected by IREE with indocyanine green (ICG). a Ordinary light observation of lymph vessels around the left gastric artery. $\mathbf{b}$ Infrared ray observation of lymph vessels around left gastric region (lymph vessels (arrow); ICG positive node (arrowhead)). c Ordinary light observation of lymph vessels around the right epigastric artery. $\mathbf{d}$ Infrared ray observation around the right epigastric artery shows first drainage lymph vessels, and sentinel lymph node (SLN) (arrow). e Ordinary light observation of lymph vessels. $f$ Infrared ray observation of lymph vessels (first drainage lymph vessels (arrow); SLN (arrowhead)) [18].

nodes in patients receiving ICG. In two studies of 43 patients with a median follow-up of 4.7 years by Hirche et al. [22] and of 168 patients with a median follow-up of 30.5 months by Toh et al. [33], no lymph node recurrence was observed. In another study by Inoue [38] and colleagues, enrolling 711 patients with a median follow-up of 38 months (from 4.4 to 87.7 months), only 2 cases $(0.4 \%)$ had lymph node recurrence.

\section{ICG in SLN Detection in Other Malignant Cancers}

\section{Gastrointestinal Carcinoma}

In 2002, Kitagawa et al. used a combined method of dye and radioisotope as a tracer in SLNB which was effective for accurate SNL sampling in early-stage gastric cancers [39]. The first study to determine the feasibility of SLNB guided by ICG fluorescence imaging in gastrointestinal caners was performed by Kusano et al. in 2008 [40]. In 26 colorectal and 22 gastric cancer patients, the SLNs and lymphatic vessels of the tumor could be visualized by fluorescence imaging when the ICG solution was injected subserosa around the tumors. In gastric cancer and colorectal cancer patients, the SN detection rates of 90.0 and $88.5 \%$ and mean number of SNs of $3.6 \pm 4.5$ and $2.6 \pm 2.4$, respectively, were detected. Furthermore, gastric cancer patients with T1 stage disease had the accuracy and false-negative rates of 88.9 and $33.3 \%$, respectively, while $100 \%$ accuracy and $0 \%$ falsenegative rate were observed in $\mathrm{T} 1$ stage colorectal cancers. Thus, the results showed that ICG fluorescence imaging allowed easy, sensitive, and real-time imaging-guided SLNB in patients with gastric and colorectal cancers and should be further explored.

SLNB guided by ICG fluorescence imaging was also used in laparoscopic surgeries for gastric cancers. In 2010, Tajima et al. used this procedure effectively in patients with $\mathrm{cT} 1$ or cT2 stage gastric cancers [41]. Either laparoscopic-assisted gastrectomy (LAG) or open gastrectomy (OG) was performed on 38 and 39 patients with $\mathrm{T} 1$ or T2 stage cancers, respectively, by using ICG fluorescence imaging. The detection rate and mean number of fluorescence nodes were reported to be $94.7 \%$ and 7.9 in the LAG group and $94.9 \%$ and 7.2 in the OG group, 
Table 1. Studies using ICG for SLNB in breast cancer patients since 2010 (more than 40 cases enrolled)

\begin{tabular}{|c|c|c|c|c|c|c|c|c|}
\hline Year & Authors & Patient no. & $\mathrm{LN}(+)$ no. & Method & IR \% & FNR \% & Mean no. & Country \\
\hline $\begin{array}{l}2010 \\
2010\end{array}$ & $\begin{array}{l}\text { Hirche et al. } \\
\text { Hojo et al. }\end{array}$ & $\begin{array}{l}43 \\
113 \text { (group 1) } \\
29(\text { group 2) }\end{array}$ & 18 & $\begin{array}{l}\text { ICG } \\
\text { Group 1: ICG + patent blue } \\
\text { Group 2: ICG }+99 \mathrm{mTc} \text {-labeled } \\
\quad \text { phytateradiocolloid }\end{array}$ & $\begin{array}{l}97.7 \\
92.9(\mathrm{BD}) \\
100(\mathrm{RI}) \\
99.3(\mathrm{ICG})\end{array}$ & 5.6 & $\begin{array}{l}2.0 \\
1.9(\mathrm{BD}) \\
2.0(\mathrm{RI}) \\
3.8(\mathrm{ICG})\end{array}$ & $\begin{array}{l}\text { German } \\
\text { Japan }\end{array}$ \\
\hline 2010 & Sugie et al. & 411 & 39 & ICG + patent blue & 99.3 & 0 & 2.3 & Japan \\
\hline 2011 & Abe et al. & 128 & 19 & $\mathrm{ICG}+$ indigo carmine & $\begin{array}{l}100(\mathrm{ICG}) \\
66(\mathrm{BD})\end{array}$ & $\begin{array}{l}0 \text { (ICG) } \\
42(\mathrm{BD})\end{array}$ & $\begin{array}{l}3.1 \text { (ICG) } \\
1.0(\mathrm{BD})\end{array}$ & Japan \\
\hline 2011 & Hirano et al. & $\begin{array}{l}393(\text { group 1) } \\
108(\text { group } 2)\end{array}$ & & $\begin{array}{l}\text { Group 1: sulfan blue } \\
\text { Group 2: ICG }+ \text { sulfan blue }\end{array}$ & $\begin{array}{l}99.1 \text { (ICG) } \\
95.0 \text { (BD) }\end{array}$ & & $\begin{array}{l}1.6(\mathrm{BD}) \\
2.2(\mathrm{ICG}+\mathrm{BD})\end{array}$ & Japan \\
\hline 2011 & Aoyama et al. & 312 & & ICG & 100 & & 3.4 & \\
\hline 2012 & Hirche et al. & 47 & 19 & ICG & 97.9 & 5.3 & 2.0 & German \\
\hline 2012 & Wishart et al. & 104 & & $\begin{array}{l}\mathrm{ICG}+99 \mathrm{mTc} \text {-labeled } \\
\quad \text { radiocolloid + patent blue }\end{array}$ & $\begin{array}{l}100(\mathrm{ICG}) \\
91.3(\mathrm{RI}) \\
99(\mathrm{BD})\end{array}$ & & $\begin{array}{l}1.9 \text { (ICG) } \\
1.5 \text { (RI) } \\
1.84 \text { (BD) }\end{array}$ & UK \\
\hline 2013 & Sugie et al. & 99 & & ICG + indigo carmine & $\begin{array}{l}99 \text { (ICG) } \\
78 \text { (BD) }\end{array}$ & & $\begin{array}{l}3.4 \text { (ICG) } \\
\text { No stated (BD) }\end{array}$ & Japan \\
\hline 2013 & Guo et al. & $\begin{array}{l}36 \text { (group 1) } \\
32 \text { (group 2) }\end{array}$ & $\begin{array}{l}19(\text { group } 1) \\
15(\text { group } 2)\end{array}$ & $\begin{array}{l}\text { Group 1: ICG } \\
\text { Group 2: patent blue }\end{array}$ & $\begin{array}{l}97.2 \text { (ICG) } \\
81.3 \text { (BD) }\end{array}$ & $\begin{array}{l}5.3(\mathrm{ICG}) \\
6.6(\mathrm{BD})\end{array}$ & $\begin{array}{l}3.6 \text { (ICG) } \\
2.1(\mathrm{BD})\end{array}$ & China \\
\hline 2014 & Guo et al. & 86 & 25 & $\mathrm{ICG}+$ patent blue & $\begin{array}{l}93 \text { (ICG) } \\
98.8 \text { (combined) }\end{array}$ & $\begin{array}{l}12 \text { (ICG) } \\
4 \text { (combined) }\end{array}$ & $\begin{array}{l}2.4 \text { (ICG) } \\
3.6 \text { (combined) }\end{array}$ & China \\
\hline 2014 & Jung et al. & $\begin{array}{l}43(\text { group 1) } \\
43(\text { group } 2)\end{array}$ & & $\begin{array}{l}\text { Group 1: ICG }+99 \mathrm{mTc} \text {-labeled } \\
\quad \text { radiocolloid + Evans blue; } \\
\text { Group 2: } 99 \mathrm{mTc} \text { Tabeled } \\
\quad \text { radiocolloid }\end{array}$ & $\begin{array}{l}100(\mathrm{ICG}) \\
100(\mathrm{RI}) \\
90.7(\mathrm{BD})\end{array}$ & & $\begin{array}{l}3.4 \text { (combined) } \\
2.3(\mathrm{RI})\end{array}$ & Korea \\
\hline 2014 & Tong et al. & $\begin{array}{l}96 \text { (group 1) } \\
73 \text { (group 2) }\end{array}$ & $\begin{array}{l}29 \text { (group 1) } \\
18 \text { (group 2) }\end{array}$ & $\begin{array}{l}\text { Group 1: ICG + patent blue; } \\
\text { Group 2: patent blue }\end{array}$ & $\begin{array}{l}96.9(\text { group 1) } \\
84.9 \text { (group 2) }\end{array}$ & $\begin{array}{l}3.4(\text { group 1) } \\
11.1 \text { (group } 2)\end{array}$ & $\begin{array}{l}3.8(\text { group } 1) \\
2.4(\text { group } 2)\end{array}$ & China \\
\hline 2014 & Verbeek et al. & 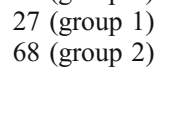 & & $\begin{array}{l}\text { Group 1: ICG }+99 \mathrm{mTc} \text {-labeled } \\
\quad \text { radiocolloid }+ \text { patent blue } \\
\text { Group 2: ICG }+99 \mathrm{mTc} \text {-labeled } \\
\quad \text { radiocolloid }\end{array}$ & $\begin{array}{l}99 \text { (ICG) } \\
\text { No stated (RI) } \\
\text { No stated (BD) }\end{array}$ & $\begin{array}{l}0(\mathrm{ICG}) \\
9(\mathrm{RI}) \\
40(\mathrm{BD})\end{array}$ & $\begin{array}{l}1.9 \text { (ICG) } \\
\text { No stated (RI) } \\
\text { No stated (BD) }\end{array}$ & Japan \\
\hline 2014 & Inoue et al. & 714 & & $\mathrm{ICG}+$ patent blue & 99.6 (combined) & & 2.4 (combined) & Japan \\
\hline 2015 & Toh et al. & 168 & 16 & ICG + indigo carmine & $\begin{array}{l}100 \text { (ICG) } \\
\text { No stated (BD) }\end{array}$ & 6.2 (ICG) & 3.0 & Japan \\
\hline 2015 & Samorani et al. & 301 & & $\begin{array}{l}\mathrm{ICG}+99 \mathrm{mTc} \text {-labeled } \\
\text { radiocolloid }\end{array}$ & $\begin{array}{l}98.7 \text { (ICG) } \\
95.4(\mathrm{RI})\end{array}$ & & $\begin{array}{l}1.94 \text { (ICG) } \\
1.62(\mathrm{RI})\end{array}$ & Italy \\
\hline 2015 & Pitsinis et al. & 50 & & $\mathrm{ICG}+$ patent blue & $\begin{array}{l}100(\mathrm{ICG}) \\
96(\mathrm{BD})\end{array}$ & & 1.8 (combined) & Greece \\
\hline 2016 & Sugie et al. & 4345 (total) & 180 & $\begin{array}{l}\mathrm{ICG}+99 \mathrm{mTc} \text {-labeled } \\
\text { radiocolloid }\end{array}$ & $\begin{array}{l}99.8 \text { (combined) } \\
97.2 \text { (ICG) } \\
97 \text { (RI) } \\
\text { Range (median) } \\
93-100(99.05) \\
\quad \text { (ICG) } \\
66-99(90.7)(\mathrm{BD}) \\
91.3-100(97)(\mathrm{RI}) \\
96.9-99.6(99.05) \\
\quad(\mathrm{ICG}+\mathrm{BD}) \\
99.8(\mathrm{ICG}+\mathrm{RI})\end{array}$ & $\begin{array}{l}2.8 \text { (combined) } \\
6.7 \text { (ICG) } \\
10 \text { (RI) } \\
\text { Range (median) } \\
0-12(5.45) \\
\quad \text { (ICG) }\end{array}$ & $\begin{array}{l}2.4 \text { (combined) } \\
2.3 \text { (ICG) } \\
1.7 \text { (RI) } \\
\text { Range (median) } \\
1.9-3.8(2.35) \\
\text { (ICG) } \\
1.0-2.4(1.87)(\mathrm{BD}) \\
1.5-2.3(1.7)(\mathrm{RI}) \\
1.8-3.6(2.4) \\
\text { (ICG + BD) } \\
2.4-3.4(2.9) \\
\text { (ICG + RI) }\end{array}$ & Japan \\
\hline
\end{tabular}

$I R$ identification rate, $F N R$ false-negative rate, $R I$ radioisotope, $B D$ blue dye, $I C G$ indocyanine green, $S L N$ sentinel lymph node, $S L N B$ sentinel lymph node biopsy

while the accuracy and false-negative rate were 97.25 and $25.0 \%$ in the LAG group and 91.9 and $23.1 \%$ in the OG group. Emile et al. performed a meta-analysis on 12 studies including 248 patients and concluded that the median sensitivity, specificity, and accuracy of detection of colonic cancer SLN by ICG were $73.7,100$, and $75.7 \%$, respectively [42].

\section{Gynecological Carcinoma}

By using SLNB in gynecological carcinoma, complications of a complete lymphadenectomy, especially the rate of lymphedema, could be decreased [43]. Several researchers compared
ICG, blue dye, and $\left[{ }^{99 \mathrm{~m}} \mathrm{Tc}\right]$ colloid in SLNBs of gynecological carcinomas. In 2016, Buda et al. performed a study in women with stage I endometrial or cervical cancers to compare the detection rate and optimal bilateral mapping by using ICG versus $\left[{ }^{99 \mathrm{~m}} \mathrm{Tc}\right]$ colloid plus blue dye, or the blue dye alone. The detection rate of ICG was $100 \%$ and higher than those of $\left[{ }^{99 \mathrm{~m}} \mathrm{Tc}\right]$ colloid with blue dye or blue dye alone which were 97 and $89 \%$, respectively. The bilateral optimal mapping rate for ICG was also higher than that of $\left[{ }^{99 \mathrm{~m}} \mathrm{Tc}\right]$ colloid with blue dye or blue dye alone [44]. Moreover, Buda et al. reported that patients with cervical or endometrial cancers, who underwent SLNB with ICG, received a better quality of care compared with those 
with $\left[{ }^{99 \mathrm{~m}} \mathrm{Tc}\right]$ colloid or blue dye as assessed by the European Organization for Research and Treatment of Cancer [45]. The same investigators also described that using the laparoscopic procedure for cervical cancers, the detection rate and bilateral optimal mapping with ICG fluorescence mapping were significantly higher than that with ${ }^{99 \mathrm{~m}} \mathrm{Tc}-$ colloid and blue dye [46].

\section{Head and Neck Cancer}

SLNB has been used in oropharyngeal cancers, head and neck cutaneous melanoma, and nasopharyngeal cancers and has been shown to remarkably decrease the complications of the neck dissection providing a more accurate node staging of the carcinomas [47]. In 2010, Bredell et al. used ICG fluorescence to detect SLNs in patients with N0 oropharyngeal cancers [48]. ICG was injected around the tumor, and SLNs were detected using an infrared video camera on the neck area. As reported by Hayashi et al. in 2012, this technique avoided a shine-through phenomenon observed during the surgery with other techniques such as lymphoscintigraphy, patent-blue staining, and gamma probes [49]. In 2015, Chan et al. used ICG for SLNB mapping in five patients with recurrent nasopharyngeal cancers who had previously undergone radiotherapy and injected ICG around the tumor for real-time mapping during the surgery [50]. Nine sentinel lymph nodes were detected, and SLN metastasis was confirmed by pathology in three patients. Many investigators have reported better results for detecting SLNs with the combination of ICG with ${ }^{99 \mathrm{~m}} \mathrm{Tc}$-colloid compared with ICG alone [51, 52]. The research using ICG for SLNB in other malignancies mentioned above is summarized in Table 2.

\section{Perspective}

Optical molecular imaging, besides being extensively used for SLNB in malignant carcinomas, plays an important role in other surgical fields. A few examples of the use of optical imaging emerging as a powerful new tool include the following:

1. To ensure the location of metastatic carcinomas and aid in surgical resection. The feasibility of applying optical molecular imaging in clinical settings was demonstrated in 2011 by Van Dam et al., who applied the FITC-labeled folic acid probe to confirm the location and the extent of metastasis in ovarian cancer patients and to excise the tumor precisely [15].

2. To confirm the margins of malignant carcinomas. In 2015, Ueo and colleagues developed the $\gamma$-glutamyl hydroxymethyl rhodamine green probe, which, when combined with GGT, could generate the green fluorescence highly beneficial for accurate incision of margins in patients undergoing breast-conserving surgery [53].

3. To protect nerve functions, when the fluorescence-labeled phage polypeptide was injected into mice, the peripheral nerves could be visualized in $2 \mathrm{~h}$, and the effect lasted for as long as $8 \mathrm{~h}$ [54]. With this probe, surgeons can benefit in repairing the injured nerves or preventing nerve injury during the operation. This technique is successfully being applied in clinical settings [55].

In addition, targeted multimodal molecular imaging probes have grabbed increasing attention. In the basic research of malignant tumors such as breast cancer, liver cancer, and gastric

Table 2. Studies using ICG for SLNB in other malignancies

\begin{tabular}{|c|c|c|c|c|c|c|c|c|}
\hline & Year & Authors & Patient no. & Method & IR \% & FNR \% & Mean no. & Country \\
\hline \multirow[t]{5}{*}{$\begin{array}{l}\text { Gastrointestinal } \\
\text { carcinoma }\end{array}$} & 2008 & Kusano et al. & $\begin{array}{l}26 \text { (colorectal cancer) } \\
22 \text { (gastric cancer) }\end{array}$ & ICG & $\begin{array}{l}88.5 \text { (colorectal } \\
\text { cancer) }\end{array}$ & $\begin{array}{l}0 \text { (colorectal } \\
\text { cancer) }\end{array}$ & $\begin{array}{l}2.6 \text { (colorectal } \\
\text { cancer) }\end{array}$ & Japan \\
\hline & & & & & $\begin{array}{l}90 \text { (gastric } \\
\text { cancer) }\end{array}$ & $\begin{array}{l}33.3 \text { (gastric } \\
\text { cancer) }\end{array}$ & $\begin{array}{l}3.6 \text { (gastric } \\
\text { cancer) }\end{array}$ & \\
\hline & 2010 & Tajima et al. & 38 (LAG) (gastric & ICG & 94.7 (LAG) & 25 (LAG) & 7.9 (LAG) & Japan \\
\hline & & & cancer) & & 94.9 (OG) & $23.1(\mathrm{OG})$ & $7.2(\mathrm{OG})$ & \\
\hline & & & $\begin{array}{l}39(\mathrm{OG}) \text { (gastric } \\
\text { cancer) }\end{array}$ & & & & & \\
\hline \multirow{7}{*}{$\begin{array}{l}\text { Gynecological } \\
\text { carcinoma }\end{array}$} & 2016 & Buda et al. & 77 (group 1) & Group 1: 99mTc-colloid & 97 (RI + BD) & No stated & No stated & Italy \\
\hline & & & 38 (group 2) & + blue dye & 89 (BD) & & & \\
\hline & & & 48 (group 3) & Group 2: blue dye & 100 (ICG) & & & \\
\hline & & & $\begin{array}{l}\text { (118 endometrial } \\
\quad \text { cancer }+45 \\
\text { cervical cancer })\end{array}$ & Group 3: ICG & & & & \\
\hline & 2016 & Buda et al. & 76 (group 1) & Group 1: 99mTc-colloid & $96(\mathrm{RI}+\mathrm{BD})$ & No stated & No stated & Italy \\
\hline & & & 68 (group 2) & +blue dye & 100 (ICG) & & & \\
\hline & & & (144 cervical cancer) & Group 2: ICG & & & & \\
\hline \multirow[t]{5}{*}{$\begin{array}{l}\text { Head and neck } \\
\text { cancer }\end{array}$} & 2015 & Chan et al. & $\begin{array}{l}5 \text { (recurrent } \\
\text { nasopharyngeal } \\
\text { carcinoma) }\end{array}$ & ICG & 60 & No stated & 3 & China \\
\hline & 2015 & Stoffels et al. & 20 (group 1) & Group 1: 99mTc-colloid + ICG & $100(\mathrm{RI}+\mathrm{ICG})$ & No stated & No stated & Germany \\
\hline & & & 20 (group 2) & Group 2: 99mTc-colloid & 90 (RI) & & & \\
\hline & & & (40 head and neck & & & & & \\
\hline & & & $\begin{array}{l}\text { cutaneous } \\
\text { malignancies) }\end{array}$ & & & & & \\
\hline
\end{tabular}

$I R$ identification rate, $F N R$ false-negative rate, $R I$ radioisotope, $B D$ blue dye, $I C G$ indocyanine green, $S L N$ sentinel lymph node, $S L N B$ sentinel lymph node biopsy, $L A G$ laparoscopic-assisted gastrectomy, $O G$ open gastrectomy 
cancer, multimodal molecular imaging probes combined with ICG have been gradually developed and applied. By taking advantage of the near-infrared light absorption property of indocyanine green, Zheng et al. [56] developed an ICG-PLPEG nano-multifunctional probe targeting folate and studied it in mouse breast cancer cell lines. They found that the probe has a strong absorption of laser energy in the near-infrared region and can specifically kill cells that express high levels of folate and confirmed the target ability of the probe and its usage in photoacoustic therapy. Ito et al. [57] developed a multimodal imaging probe combining magnetic resonance imaging (MRI) and near-infrared fluorophore-labeled EGFR or CEA antibodies. With the probes, they sensitively detected metastases of gastric cancer cells $<1 \mathrm{~mm}$ in diameter in peritoneum of mice. Chen et al. [58] synthesized the bimodal probe, conjugating superparamagnetic iron oxide (SPIO) nanoparticles, tumortargeted agent Arg-Gly-Asp peptides (RGD) and near-infrared fluorophore dye-ICG, and performed study in rat liver cancer models. The results showed that the probe can clearly locate the tumor for accurate tumor resection. Guan et al. [59] fabricated ICG-loaded gold nanorod@liposome core-shell nanoparticles (Au@liposome-ICG) as a probe to detect mouse liver cancer. The probe exhibits excellent biocompatibility, high stability, and strong imaging signal, and can effectively perform tumor detection and guide tumor resection.

Functional multimodal molecular imaging probes combining with ICG are also applied in SLNB. By combining ICG with $\left[{ }^{99 \mathrm{~m}} \mathrm{Tc}\right]$ labeled nano-colloid, Brouwer et al. formulated a heterocomplex tracer with both fluorescence and radioactive functions for SLNB [60]. Ting and colleagues used F-18 labeled near-infrared fluorescence in SLNB to get precise images and position of lymph nodes for the excision of SLNs [61].

The optical molecular imaging technique has developed rapidly in the past 10 years and has been tremendously useful in the treatment of malignant carcinomas. The near-infrared fluorescence imaging with ICG for the SLNB in breast cancers, head and neck, gastrointestinal, and gynecological carcinomas has been extensively used. Compared with conventional methods, there is considerable improvement in the detection rate and accuracy. Raising the detection rate will help to reduce lymph node dissection caused by SLNB failure, thereby reducing postoperative complications. Increasing the accuracy rate is even more important for long-term treatment outcomes and helps reduce the risk of postoperative recurrence.

Nevertheless, this technique still has many shortcomings: There is no standard concentration of ICG; neither are there specified steps during the procedure. Also, tracing requires special devices, but the properties of the hardware and software of the devices are different which may affect the image and accuracy. Furthermore, the number of the sentinel lymph nodes detected by the ICG method is more than those detected by conventional methods posing a risk of detecting some non-sentinel lymph nodes. At present, clinical studies about the detection of SLN by ICG are mostly focused on the detection rate, accuracy, and detecting number by comparing ICG and other tracers. However, long-term follow-up data is rare and the impact on treatment outcomes remains to be determined [62].

In conclusion, a standard operation method and further optimization of the imaging system would be the important steps in advancing optical molecular imaging. The use of multiple probes, which can position the sentinel lymph nodes more precisely and detect metastatic status in real time, is another area that requires focused efforts. With the improvement in the sensitivity of the probes and verification in large clinical trials, the technique of optical molecular imaging is expected to play an increasingly important role in the treatment of malignant carcinomas.

Acknowledgments. The authors sincerely thank all participants for their lively discussion during the study group meeting.

Funding information. This work was supported by grants from Major International Collaborative Research Project of Natural Science Foundation Committee (81320108015), Research Team Project of Natural Science Foundation of Guangdong Province (2016A030312008), and start-up fund from Xiamen University.

\section{Compliance with Ethical Standards}

\section{Conflict of Interest}

The authors declare that they have no conflict of interest.

Open Access This article is distributed under the terms of the Creative Commons Attribution 4.0 International License (http:// creativecommons.org/licenses/by/4.0/), which permits unrestricted use, distribution, and reproduction in any medium, provided you give appropriate credit to the original author(s) and the source, provide a link to the Creative Commons license, and indicate if changes were made.

\section{References}

1. McGuire S (2016) World Cancer Report 2014. Geneva, Switzerland: World Health Organization, International Agency for Research on Cancer, WHO Press, 2015. Adv Nutr 7:418-419

2. Habal N, Giuliano AE, Morton DL (2001) The use of sentinel lymphadenectomy to identify candidates for postoperative adjuvant therapy of melanoma and breast cancer. Semin Oncol 28:41-52

3. Cochran AJ, Wen DR, Morton DL (1988) Occult tumor cells in the lymph nodes of patients with pathological stage I malignant melanoma. An immunohistological study. Am J Surg Pathol 12:612-618

4. Giuliano AE, Kirgan DM, Guenther JM, Morton DL (1994) Lymphatic mapping and sentinel lymphadenectomy for breast cancer. Ann Surg 220:391-398 discussion 398-401

5. Krag DN, Weaver DL, Alex JC, Fairbank JT (1993) Surgical resection and radiolocalization of the sentinel lymph node in breast cancer using a gamma probe. Surg Oncol 2:335-339 discussion 340

6. Krag DN, Anderson SJ, Julian TB, Brown AM, Harlow SP, Ashikaga T, Weaver DL, Miller BJ, Jalovec LM, Frazier TG, Noyes RD, Robidoux A, Scarth HM, Mammolito DM, McCready D, Mamounas EP, Costantino JP, Wolmark N, National Surgical Adjuvant Breast and Bowel Project (2007) Technical outcomes of sentinel-lymph-node resection and conventional axillary-lymph-node dissection in patients with clinically node-negative breast cancer: results from the NSABP B-32 randomised phase III trial. Lancet Oncol 8:881-888

7. Latosinsky S, Dabbs K, Moffat F (2008) Canadian Association of General Surgeons and American College of surgeons evidence-based reviews in surgery. 27. Quality-of-life outcomes with sentinel node biopsy versus standard axillary treatment in patients with operable breast cancer. Randomized multicenter trial of sentinel node biopsy versus standard axillary treatment in operable breast cancer: the ALMANAC trial. Can J Surg 51:483-485 
8. Veronesi U, Paganelli G, Viale G, Luini A, Zurrida S, Galimberti V, Intra M, Veronesi P, Robertson C, Maisonneuve P, Renne G, de Cicco C, de Lucia F, Gennari R (2003) A randomized comparison of sentinel-node biopsy with routine axillary dissection in breast cancer. N Engl J Med 349:546-553

9. Qiu SQ, Zhang GJ, Jansen L, de Vries J, Schröder CP, de Vries EGE, van Dam GM (2018) Evolution in sentinel lymph node biopsy in breast cancer. Crit Rev Oncol Hematol 123:83-94

10. Nguyen QT, Olson ES, Aguilera TA, Jiang T, Scadeng M, Ellies LG, Tsien RY (2010) Surgery with molecular fluorescence imaging using activatable cell-penetrating peptides decreases residual cancer and improves survival. Proc Natl Acad Sci U S A 107:4317-4322

11. Reinhart MB, Huntington CR, Blair LJ, Heniford BT, Augenstein VA (2016) Indocyanine green: historical context, current applications, and future considerations. Surg Innov 23:166-175

12. Chi C, Du Y, Ye J et al (2014) Intraoperative imaging-guided cancer surgery: from current fluorescence molecular imaging methods to future multi-modality imaging technology. Theranostics 4:1072-1084

13. Liu Y, Njuguna R, Matthews T, Akers WJ, Sudlow GP, Mondal S, Tang R, Gruev V, Achilefu S (2013) Near-infrared fluorescence goggle system with complementary metal-oxide-semiconductor imaging sensor and see-through display. J Biomed Opt 18:101303

14. Lee BT, Hutteman M, Gioux S, Stockdale A, Lin SJ, Ngo LH, Frangioni JV (2010) The FLARE intraoperative near-infrared fluorescence imaging system: a first-in-human clinical trial in perforator flap breast reconstruction. Plast Reconstr Surg 126:1472-1481

15. van Dam GM, Themelis G, Crane LM, Harlaar NJ, Pleijhuis RG, Kelder W, Sarantopoulos A, de Jong JS, Arts HJ, van der Zee A, Bart J, Low PS, Ntziachristos V (2011) Intraoperative tumor-specific fluorescence imaging in ovarian cancer by folate receptor-alpha targeting: first in-human results. Nat Med 17:1315-1319

16. Chi C, Ye J, Ding H, He D, Huang W, Zhang GJ, Tian J (2013) Use of indocyanine green for detecting the sentinel lymph node in breast cancer patients: from preclinical evaluation to clinical validation. PLoS One 8:e83927

17. Glatz J, Varga J, Garcia-Allende PB, Koch M, Greten FR, Ntziachristos V (2013) Concurrent video-rate color and near-infrared fluorescence laparoscopy. J Biomed Opt 18:101302

18. Mitsumori N, Nimura H, Takahashi N, Kawamura M, Aoki H, Shida A, Omura N, Yanaga K (2014) Sentinel lymph node navigation surgery for early stage gastric cancer. World J Gastroenterol 20(19):5685-5569

19. Kitai T, Inomoto T, Miwa M, Shikayama T (2005) Fluorescence navigation with indocyanine green for detecting sentinel lymph nodes in breast cancer. Breast Cancer 12:211-215

20. Ogasawara Y, Ikeda H, Takahashi M, Kawasaki K, Doihara H (2008) Evaluation of breast lymphatic pathways with indocyanine green fluorescence imaging in patients with breast cancer. World J Surg 32:1924-1929

21. Murawa D, Hirche C, Dresel S, Hunerbein M (2009) Sentinel lymph node biopsy in breast cancer guided by indocyanine green fluorescence. Br J Surg 96:1289-1294

22. Hirche C, Murawa D, Mohr Z, Kneif S, Hünerbein M (2010) ICG fluorescence-guided sentinel node biopsy for axillary nodal staging in breast cancer. Breast Cancer Res Treat 121:373-378

23. Hojo T, Nagao T, Kikuyama M, Akashi S, Kinoshita T (2010) Evaluation of sentinel node biopsy by combined fluorescent and dye method and lymph flow for breast cancer. Breast 19:210-213

24. Sugie T, Kassim KA, Takeuchi M, Hashimoto T, Yamagami K, Masai Y, Toi M (2010) A novel method for sentinel lymph node biopsy by indocyanine green fluorescence technique in breast cancer. Cancers (Basel) 2:713-720

25. Abe H, Mori T, Umeda T, Tanaka M, Kawai Y, Shimizu T, Cho H, Kubota Y, Kurumi Y, Tani T (2011) Indocyanine green fluorescence imaging system for sentinel lymph node biopsies in early breast cancer patients. Surg Today 41:197-202

26. Hirche C, Mohr Z, Kneif S, Murawa D, Hünerbein M (2012) High rate of solitary sentinel node metastases identification by fluorescenceguided lymphatic imaging in breast cancer. J Surg Oncol 105:162-166

27. Guo W, Zhang L, Ji J, Gao W, Liu J, Tong M (2014) Breast cancer sentinel lymph node mapping using near-infrared guided indocyanine green in comparison with blue dye. Tumour Biol 35:3073-3078

28. Yamamoto S, Maeda N, Yoshimura K, Oka M (2013) Intraoperative detection of sentinel lymph nodes in breast cancer patients using ultrasonography-guided direct indocyanine green dye-marking by real-time virtual sonography constructed with three-dimensional computed tomography-lymphography. Breast 22:933-937

29. Samorani D, Fogacci T, Panzini I, Frisoni G, Accardi FG, Ricci M, Fabbri E, Nicoletti S, Flenghi L, Tamburini E, Tassinari D, Gianni L (2015) The use of indocyanine green to detect sentinel nodes in breast cancer: a prospective study. Eur J Surg Oncol 41:64-70

30. Sugie T, Kinoshita T, Masuda N, Sawada T, Yamauchi A, Kuroi K, Taguchi T, Bando H, Yamashiro H, Lee T, Shinkura N, Kato H, Ikeda T, Yoshimura K, Ueyama H, Toi M (2016) Evaluation of the clinical utility of the ICG fluorescence method compared with the radioisotope method for sentinel lymph node biopsy in breast cancer. Ann Surg Oncol 23:44-50

31. Pitsinis V, Provenzano E, Kaklamanis L, Wishart GC, Benson JR (2015) Indocyanine green fluorescence mapping for sentinel lymph node biopsy in early breast cancer. Surg Oncol 24:375-379

32. Verbeek FP, Troyan SL, Mieog JS et al (2014) Near-infrared fluorescence sentinel lymph node mapping in breast cancer: a multicenter experience. Breast Cancer Res Treat 143:333-342

33. Toh U, Iwakuma N, Mishima M, Okabe M, Nakagawa S, Akagi Y (2015) Navigation surgery for intraoperative sentinel lymph node detection using Indocyanine green (ICG) fluorescence real-time imaging in breast cancer. Breast Cancer Res Treat 153:337-344

34. Zhang X, Li Y, Zhou Y, Mao F, Lin Y, Guan J, Sun Q (2016) Diagnostic performance of indocyanine green-guided sentinel lymph node biopsy in breast cancer: a meta-analysis. PLoS One 11:e0155597

35. Guo W, Zhang L, Ji J, Gao W, Liu J, Tong M (2014) Evaluation of the benefit of using blue dye in addition to indocyanine green fluorescence for sentinel lymph node biopsy in patients with breast cancer. World J Surg Oncol 12:290

36. Tong M, Guo W, Gao W (2014) Use of fluorescence imaging in combination with patent blue dye versus patent blue dye alone in sentinel lymph node biopsy in breast cancer. J Breast Cancer 17:250255

37. Obana A, Miki T, Hayashi K, Takeda M, Kawamura A, Mutoh T, Harino S, Fukushima I, Komatsu H, Takaku Y, Shiraga F, Matsuhashi H, Torii Y, Masaoka N, Kondoh T, Hasegawa Y (1994) Survey of complications of indocyanine green angiography in Japan. Am J Ophthalmol 118:749-753

38. Inoue T, Nishi T, Nakano Y, Nishimae A, Sawai Y, Yamasaki M, Inaji H (2016) Axillary lymph node recurrence after sentinel lymph node biopsy performed using a combination of indocyanine green fluorescence and the blue dye method in early breast cancer. Breast Cancer 23:295-300

39. Kitagawa Y, Fujii H, Mukai M, Kubota T, Otani Y, Kitajima M (2002) Radio-guided sentinel node detection for gastric cancer. Br J Surg 89:604-608

40. Kusano M, Tajima Y, Yamazaki K, Kato M, Watanabe M, Miwa M (2008) Sentinel node mapping guided by indocyanine green fluorescence imaging: a new method for sentinel node navigation surgery in gastrointestinal cancer. Dig Surg 25:103-108

41. Tajima Y, Murakami M, Yamazaki K, Masuda Y, Kato M, Sato A, Goto S, Otsuka K, Kato T, Kusano M (2010) Sentinel node mapping guided by indocyanine green fluorescence imaging during laparoscopic surgery in gastric cancer. Ann Surg Oncol 17:1787-1793

42. Emile SH, Elfeki H, Shalaby M, Sakr A, Sileri P, Laurberg S, Wexner SD (2017) Sensitivity and specificity of indocyanine green nearinfrared fluorescence imaging in detection of metastatic lymph nodes in colorectal cancer: systematic review and meta-analysis. J Surg Oncol 116:730-740

43. Rossi EC, Ivanova A, Boggess JF (2012) Robotically assisted fluorescence-guided lymph node mapping with ICG for gynecologic malignancies: a feasibility study. Gynecol Oncol 124:78-82

44. Buda A, Crivellaro C, Elisei F, di Martino G, Guerra L, de Ponti E, Cuzzocrea M, Giuliani D, Sina F, Magni S, Landoni C, Milani R (2016) Impact of indocyanine green for sentinel lymph node mapping in early stage endometrial and cervical cancer: comparison with conventional radiotracer ${ }^{99 \mathrm{~m}} \mathrm{Tc}$ and/or blue dye. Ann Surg Oncol 23:2183-2191

45. Buda A, Elisei F, Palazzi S, de Ponti E, Arosio M, Vecchione F, Dell'Anna T, Cuzzocrea M, Bussi B, Giuliani D, di Martino G, Crivellaro C (2016) Quality of care for cervical and endometrial cancer patients: the impact of different techniques of sentinel lymph node mapping on patient satisfaction. Ann Surg Oncol 23:2975-2981 
46. Buda A, Papadia A, Zapardiel I, Vizza E, Ghezzi F, de Ponti E, Lissoni AA, Imboden S, Diestro MD, Verri D, Gasparri ML, Bussi B, di Martino G, de la Noval BD, Mueller M, Crivellaro C (2016) From conventional radiotracer Tc-99(m) with blue dye to indocyanine green fluorescence: a comparison of methods towards optimization of sentinel lymph node mapping in early stage cervical cancer for a laparoscopic approach. Ann Surg Oncol 23:2959-2965

47. van der Vorst JR, Schaafsma BE, Verbeek FP et al (2013) Nearinfrared fluorescence sentinel lymph node mapping of the oral cavity in head and neck cancer patients. Oral Oncol 49:15-19

48. Bredell MG (2010) Sentinel lymph node mapping by indocyanin green fluorescence imaging in oropharyngeal cancer-preliminary experience. Head Neck Oncol 2:31

49. Hayashi T, Furukawa H, Oyama A, Funayama E, Saito A, Yamao T, Yamamoto Y (2012) Sentinel lymph node biopsy using real-time fluorescence navigation with indocyanine green in cutaneous head and neck/lip mucosa melanomas. Head Neck 34:758-761

50. Chan JY, Tsang RK, Wong ST, Wei WI (2015) Indocyanine green fluorescence mapping of sentinel lymph node in patients with recurrent nasopharyngeal carcinoma after previous radiotherapy. Head Neck 37:E169-E173

51. Stoffels I, Leyh J, Poppel T et al (2015) Evaluation of a radioactive and fluorescent hybrid tracer for sentinel lymph node biopsy in head and neck malignancies: prospective randomized clinical trial to compare ICG ${ }^{99 \mathrm{~m}}$ Tc-nanocolloid hybrid tracer versus $99 \mathrm{~m}$ Tcnanocolloid. Eur J Nucl Med Mol Imaging 42:1631-1638

52. KleinJan GH, Karakullukcu B, Klop WMC et al (2017) Introducing navigation during melanoma-related sentinel lymph node procedures in the head-and-neck region. EJNMMI Res 7:65

53. Ueo H, Shinden Y, Tobo T, Gamachi A, Udo M, Komatsu H, Nambara S, Saito T, Ueda M, Hirata H, Sakimura S, Takano Y, Uchi R, Kurashige J, Akiyoshi S, Iguchi T, Eguchi H, Sugimachi K, Kubota Y, Kai Y, Shibuta K, Kijima Y, Yoshinaka H, Natsugoe S, Mori M, Maehara Y, Sakabe M, Kamiya M, Kakareka JW, Pohida TJ, Choyke PL, Kobayashi H, Ueo H, Urano Y, Mimori K (2015) Rapid intraoperative visualization of breast lesions with gamma-glutamyl hydroxymethyl rhodamine green. Sci Rep 5:12080
54. Wu AP, Whitney MA, Crisp JL, Friedman B, Tsien RY, Nguyen QT (2011) Improved facial nerve identification with novel fluorescently labeled probe. Laryngoscope 121:805-810

55. Whitney MA, Crisp JL, Nguyen LT, Friedman B, Gross LA, Steinbach P, Tsien RY, Nguyen QT (2011) Fluorescent peptides highlight peripheral nerves during surgery in mice. Nat Biotechnol 29:352-356

56. Zheng X, Xing D, Zhou F, Wu B, Chen WR (2011) Indocyanine green-containing nanostructure as near infrared dual-functional targeting probes for optical imaging and photothermal therapy. Mol Pharm 8:447-456

57. Ito A, Ito Y, Matsushima S, Tsuchida D, Ogasawara M, Hasegawa J, Misawa K, Kondo E, Kaneda N, Nakanishi H (2014) New wholebody multimodality imaging of gastric cancer peritoneal metastasis combining fluorescence imaging with ICG-labeled antibody and MRI in mice. Gastric Cancer 17:497-507

58. Chen Q, Shang W, Zeng C, Wang K, Liang X, Chi C, Liang X, Yang J, Fang C, Tian J (2017) Theranostic imaging of liver cancer using targeted optical/MRI dual-modal probes. Oncotarget 8:32741-32751

59. Guan T, Shang W, Li HY et al (2017) From detection to resection: photoacoustic tomography and surgery guidance with indocyanine green loaded gold nanorod@liposome core-shell Nanoparticles in Liver Cancer. Bioconjug Chem 28:1221-1228

60. Frontado LM, Brouwer OR, van den Berg NS, Mathéron HM, VidalSicart S, van Leeuwen F, Valdés Olmos RA (2013) Added value of the hybrid tracer indocyanine green- ${ }^{99 \mathrm{~m}}$ Tc-nanocolloid for sentinel node biopsy in a series of patients with different lymphatic drainage patterns. Rev Esp Med Nucl Imagen Mol 32:227-233

61. Ting R, Aguilera TA, Crisp JL, Hall DJ, Eckelman WC, Vera DR, Tsien RY (2010) Fast ${ }^{18} \mathrm{~F}$ labeling of a near-infrared fluorophore enables positron emission tomography and optical imaging of sentinel lymph nodes. Bioconjug Chem 21:1811-1819

62. Ahmed M, Purushotham AD, Douek M (2014) Novel techniques for sentinel lymph node biopsy in breast cancer: a systematic review. Lancet Oncol 15:e351-e362 